\title{
Affecting Factors on the Implementation of the Learning Outcomes Evaluation: A Case Study at Senior High School in Palu
}

\author{
Suyuti \\ Universitas Tadulako \\ Palu, Indonesia \\ suyutianur@yahoo.co.id
}

\begin{abstract}
The learning outcome evaluation is a tool to obtain an information about learning objectives whether or not they are successfully achieved and even to know the quality of national education. Therefore, implementation of the learning outcomes evaluation is important to be deeply discussed. This study aims to determine factors that influence the implementation of the learning outcomes evaluation that is carried out by not only by a teacher and a school, but also the government. The study used the qualitative descriptive method. Data collection techniques involved observation, interviews, and questionnaires. The data were analyzed by using interactive data analysis. Results of the study are as follows: First, the external factors that influenced the evaluation consisted of: a) the evaluation administration system that was regulated imposed by the government or the curriculum, b) Teachers who used to administer the evaluation of learning outcomes, c) the capability and habit of the schools in implementing the evaluation of learning outcomes. Second, factors from the students comprised: a) negative attitude towards the implementation of the learning outcomes evaluation, b) poor behavior of the students when the implementation of learning outcomes evaluation was done.
\end{abstract}

Keywords-factors; implementation; evaluation; learning outcomes.

\section{INTRODUCTION}

Regulation of the Minister of Education and Culture of the Republic of Indonesia number 23 of 2016 on Education Assessment Standards states that the assessment is the process of collecting and processing information to measure the achievement of learners' learning outcomes. The objectives of the Evaluation of Student Learning Outcomes are: (1) Assessment of learning outcomes by educators aims to monitor and evaluate the process, learning progress, and improvement of learning outcomes of students continuously; (2) Assessment of learning outcomes by the Education Unit aims to assess the achievement of the Graduate Competency Standards for all subjects; And (3) Assessment of learning outcomes by the Government aims to assess the achievement of national graduate competencies in certain subjects. Thus it can be seen that the scope of the assessment of education, especially in Primary and Secondary Education consists of; A) Assessment of learning outcomes by educators, b) Assessment of learning outcomes by educational units; And c) Assessment of learning outcomes by the Government. Thus, it is the responsibility to carry out the assessment of learning outcomes are the three components.
Evaluation of learning outcomes by educators is done on an ongoing basis to monitor the process, progress, and improvement of results in the form of daily repetition, midterm replay, semester final repetition, and grade repetition. Evaluation of learning outcomes by educators is used to assess the achievement of the competencies of learners; Preparation of reports of learning outcomes; And improve the learning process. Evaluation of learning outcomes by educational unit aims to assess the achievement of graduate competency standards for all subjects. Evaluation of learning outcomes by the government in the form of National Exam aims to assess the achievement of national graduate competence on certain subjects in science and technology subjects. National examinations are conducted in an objective, fair, and accountable manner. National exam results are used as a consideration for (a) mapping of program quality and/or educational unit; (B) selection consideration for the next level of education; And (c) coaching and providing assistance to educational units in its efforts to improve the quality of education.

In order to achieve the results as expected, the evaluation of the learning outcomes uses the principles set forth in Chapter IV, Article 5, which should be: Sahih, objective, fair, integrated, open, comprehensive, systematic, criteria and accountable (Permendikbud No. 23 of 2016: 4-5). In relation to the accountability issues of the appraisal principle, the assessment instruments used are: a) assessment instruments used by educators in the form of assessment in the form of tests, observations, assignments of individuals or groups, and other forms appropriate to the competence characteristics and developmental level of learners , B) the assessment instrument used by the educational unit in the form of a final assessment and / or a school / madrasah exam meeting substance, construction, and language requirements, and having evidence of empirical validity, and c) assessment instrument used by the government in the form of a national examination UN) meets the requirements of substance, construction, language, and has evidence of empirical validity and produces comparable scores between schools, inter-regional, and inter-year.

To achieve this, the implementation of the Evaluation of Learning Outcomes, whether conducted by the Teachers (Teachers), the Education Unit (School), or by the Government (Ministry of Education and Culture) must be assured to actually run as expected. Implementation of Evaluation of True Learning Result, of course, will lead to the achievement of the National 
Education Objectives is "to form the character and civilization of a dignified nation in order to educate the nation's life, aims for the development of potential learners to become human beings who believe and cautious to God Almighty, Be noble, healthy, knowledgeable, capable, creative, independent, and become a democratic and responsible citizen ".

Therefore, this is where the purpose or benefit of this research, namely to find out how the implementation of Evaluation of Learning Outcomes that have been implemented, and what are the factors that affect the implementation so far.

\section{METHODS}

This research is a qualitative descriptive research describing Factors influencing the implementation of Student Learning Evaluation, both Evaluation of Learning conducted by Teachers, Evaluation of Learning Results conducted by Education Unit and Evaluation of Learning Outcomes conducted by the Government. In this study, the Population is a Senior High School Student in Palu City who has followed three kinds of Evaluation of Learning Outcomes with Total 796 People and the sample taken $10 \%$ to become 79.6 (80 People). Data collection techniques used questionnaires and interviews. Questionnaires are used for students while interviews are conducted on principals, teachers, and officials of the Education and Culture offices of Central Sulawesi Province. Data analysis using descriptive analysis with percentage formula to recognize data of the result of the questionnaire, while to analyze data result of an interview with the interactive model.

\section{RESULTS AND DISCUSSION}

Factors that affect the implementation of the evaluation of Learning Outcomes High School Students in the city of Palu, can be seen from several factors. That is:

\section{A. Internal Factors (from Students).}

\section{Feeling Anxious}

Students who are experiencing anxiety or fear are students who are in trouble and are in a state of depression, helplessness. Anxiety is "Unpleasant emotions characterized by terms such as" Worries, " Concerns, "and" Fears, "which are sometimes experienced on different levels [3]. In such circumstances, students are easily colonized by the forces that penetrate into him which can further weaken and cause various damage himself and failure in the face of various Evaluations/assessment results Learning held in School. Students who are troubled on the psychological aspect (anxious) are the students will experience an uncomfortable situation. His potential and energy are not developed. Student's sense of security is distracted, competence does not work, aspiration is confined, the spirit of learning is withered, and the opportunities that are open for him to succeed will be wasted. Students who have good self-esteem will not experience feelings of anxiety in the face of various learning evaluations to be undertaken. They will assume that examination is common and must be passed in the learning process. However, for students who lack confidence and are always anxious or afraid to face exams/tests that will be done, then they will tend to do things that violate the rules and regulations that apply such as cheating, etc.

This feeling of anxiety or lack of confidence is always experienced by most of the senior high school students in Palu city or maybe even other students in other areas, when they are faced with tests/tests conducted by both educators, schools and Which is done by the government. The questionnaire is distributed to 80 respondents with questions about how you feel about daily rehearsals by teachers, semester tests conducted by schools and National Exams, with open answers consisting of a. Very Anxious, b. Anxiety and C. Mediocre, the answers obtained varied. Of the three types of evaluation followed by the students, the highest level of anxiety is at the time of the National Exam conducted by the government, while the lowest level of anxiety is at the time of following the daily evaluation / repeated performed by the teacher. For more details can be seen in Table I.

TABLE I. PERCENTAGE ANXIETY LEVEL PERCEIVED BY STUDENTS DURING THE DAILY TEST ACTIVITY.

\begin{tabular}{|c|l|l|l|l|l|l|l|}
\hline No & $\begin{array}{l}\text { Type of } \\
\text { Evaluation }\end{array}$ & $\begin{array}{l}\text { Very } \\
\text { anxious }\end{array}$ & $\%$ & anxious & $\%$ & mediocre & $\%$ \\
\hline 1 & Daily test & 3 & 3,75 & 7 & 8,75 & 70 & 87,5 \\
\hline
\end{tabular}

TABLE II. PERCENTAGE ANXIETY LEVEL PERCEIVED BY THE STUDENT AT THE TIME OF FOLLOWING THE FINAL TEST.

\begin{tabular}{|l|l|l|l|l|l|l|l|}
\hline No & $\begin{array}{l}\text { Type of } \\
\text { Evaluatio } \\
\mathrm{n}\end{array}$ & $\begin{array}{l}\text { Very } \\
\text { anxiou } \\
\mathrm{s}\end{array}$ & $\%$ & $\begin{array}{l}\text { anxiou } \\
\mathrm{s}\end{array}$ & $\%$ & $\begin{array}{l}\text { mediocr } \\
\mathrm{e}\end{array}$ & $\%$ \\
\hline 2 & Final test & 7 & $\begin{array}{l}8,7 \\
5\end{array}$ & 65 & $\begin{array}{l}81,2 \\
5\end{array}$ & 13 & $\begin{array}{l}16,2 \\
5\end{array}$ \\
\hline
\end{tabular}

TABLE III. PERCENTAGE LEVEL OF ANXIETY FELT BY STUDENTS AT THE TIME OF NATIONAL TEST ACTIVITY.

\begin{tabular}{|c|l|l|l|l|l|l|l|}
\hline No & $\begin{array}{l}\text { Type of } \\
\text { Evaluation }\end{array}$ & $\begin{array}{l}\text { Very } \\
\text { anxious }\end{array}$ & $\%$ & anxious & $\%$ & mediocre & $\%$ \\
\hline 3 & $\begin{array}{l}\text { National } \\
\text { test }\end{array}$ & 73 & 91,25 & 5 & 6,25 & 2 & 2,5 \\
\hline
\end{tabular}

Based on the above data, shows that the level of anxiety felt by high school students in Palu city will follow the Evaluation of Learning Outcomes, the type of Evaluation of the highest level of anxiety is at the time will follow the National Exam, with a very anxious percentage $91.25 \%$., The second anxiety level is at the time of repeating semester with a very worried percentage of $8.75 \%$, and the third is on the daily follow-up with a very worried percentage of only $3.75 \%$.

This shows that from the three types of Evaluation Learning followed by high school students in the city of Palu, the highest level of anxiety is felt at the time will follow the National Exam. Moderate feelings or feelings are not too anxious to feel at the time will follow Daily Deuteronomy. The emergence of this Anxious feeling resulted from several things, including 1) Lack of mastery over the subject matter, 2) lack of confidence, 3) Unsuspable and unusual facing reality, 4) Assuming that Trials are a daunting thing etc.

\section{Cheating Behavior.}


As a result of excessive feelings of anxiety, the consequences are fraudulent or dishonest behavior in the face of the implementation of the evaluation of learning both exams/tests conducted by teachers, schools, and government. This fraudulent or dishonest behavior is very visible when students face daily tests or even a semester test. Fraudulent or dishonest behavior often expressed by students such as; Preparing paper notes when studying, cheating, co-operation, etc. Behavior is often influenced by the personal aspect of the individual itself. Fraudulent behavior is "consistency between beliefs as a cognitive component, a feeling as an attitude component, with behaviors as such a conative component that is the basis of attitude inference through behavioral observation" [4]. The factors behind the change in student behavior when will follow the learning evaluation activities can be known through external and internal factors. External factors stem from the role of Teacher, Parents, school. While the internal factor is the ability of students to understand the subject matter, motivation and low student interest. Regarding the cause of academic fraud, Novitasari states that a person will commit academic cheating if he or she sees others doing it or if they perceive that academic cheating is a normal and common behavior that can be accepted within the group [5]. There are four factors causing academic cheating: (1) individual or personal factors, (2) environmental factors or group influences, (3) factors of the evaluation system and (4) factors of teachers, lecturers, or assessors [6].

Based on the data from questionnaires that ask you whether you see the notes (cheat), collaborate with a friend during a learning evaluation (daily test, semester test), with a choice of answers: often, rarely and never. Answers to these questions can be seen in the following table:

TABLE IV PERCENTAGE OF FRAUD RATES INCURRED BY STUDENTS WHEN ATTENDING A LEARNING EVALUATION ACTIVITY (DAILY TEST)

\begin{tabular}{|l|l|l|l|l|l|l|l|}
\hline No & $\begin{array}{l}\text { Type of } \\
\text { Evaluation }\end{array}$ & Often & $\%$ & Rarely & $\%$ & Never & $\%$ \\
\hline 4 & Daily test & 40 & 15 & 15 & 18,75 & 25 & 31,25 \\
\hline
\end{tabular}

TABLE V PERCENTAGE OF FRAUD RATES EXPRESSED BY STUDENTS AT THE TIME OF STUDY EVALUATION (FINAL TEST)

\begin{tabular}{|l|l|l|l|l|l|l|l|}
\hline No & $\begin{array}{l}\text { Type of } \\
\text { Evaluation }\end{array}$ & Often & $\%$ & Rarely & $\%$ & Never & $\%$ \\
\hline 5 & Final Test & 65 & 81,25 & 10 & 12,5 & 5 & 5,25 \\
\hline
\end{tabular}

From the data mentioned above, it shows that from two types of learning evaluation that is done by teacher evaluation (daily examination) and evaluation of learning done by school (semester test), it turns out that the higher frequency of false prosperity during repeat, that is repeat Semester $81.25 \%$, while the percentage of the frequency of cheating on daily test only $40 \%$. After in-depth interviews, it turns out that the cause of the high percentage of frequent fraud studied at the time of repetition semester is due to lack of teacher obedience in conducting supervision. Meanwhile, the daily examination of the supervision is quite strict. Strict supervision at the time of daily test is because the supervisor is the subject teacher itself. While supervision on the semester test is the teacher of another field of study and or the committee formed. Teachers who are not in the field of study tend to be not strict / disciplined in conducting supervision at the time of the test.

Cheating is a deliberate act by a person through unfavorable means with the aim of achieving academic success and avoiding academic failure [7]. Others argue that cheating is an attempt by a person to gain success in dishonest ways [8]. Cheating culture can be caused by the influence of groups where people tend to dare to do because they see others in the group also do. The form of cheating that is often done by students can be divided into two, namely; 1) cheat by own effort, by making small notes, opening a book, with other tools such as making strokes on small papers, tables, formulas in hand or looking at friends' answers, 2) cheating by cooperation, for example: making Deal in advance and make certain codes to request answers from friends [9]. The occurrence of cheating culture among students, due to lack of self-confidence when students do repetition questions that make students always ask friends to convince the answer. Other causes that cause the culture of cheating is caused by the pressure from various parties to get good grades, but because students have a lazy nature of learning so that students take shortcuts by making cheat as a habit when repetition takes place.

Another case with the cheating that occurred on the national exam. In the national examination, the fraud happens is in the form of cooperation between students and students and between students with teachers and even cooperation between students with other parties who aim to get the benefits behind the implementation of the national exam. The fact that the fraud occurred in every national exam in almost all regions cannot be denied. Every year a lot of media preach about this, even last year came to the term "Team Success". The term is very ironic because this term is only known at the time of the election of the regional head or the political life event. The question that arises is whether the implementation of this national exam has also entered the political sphere? So that so many issues that arise around the implementation of this national exam. To answer it, of course, need special research. The result of an interview with one of the senior high school teachers in Palu City stated that it was true that he participated in giving answers to the students during the national examination on the matter that the teacher was assigned as an in-house supervisor. When asked more why he did it, the answer was feeling "pity" with students who had studied for three years, but the graduation was determined only three days. And it goes on to state that "we are teachers who know better about who our son really is, but rather the central government, in this case, the Ministry of Education and Culture even greater determination of its graduation (40\% School, $60 \%$ Center), even though it has now been converted into a national examination No longer determinants of graduation.

Based on the data obtained in relation to the question that is asked: "Do you have the key answer before taking the national exam last year? And if you've got the key answer, through whom you get the key answer? 
TABLE VI PERCENTAGE OF STUDENT INVOLVEMENT OBTAINS KEY ANSWER BEFORE FOLLOWING NATIONAL TEST

\begin{tabular}{|l|l|l|l|l|l|l|l|}
\hline No & $\begin{array}{l}\text { Type of } \\
\text { Evaluation }\end{array}$ & $\begin{array}{l}\text { Has } \\
\text { Whole }\end{array}$ & $\%$ & owns & $\%$ & $\begin{array}{l}\text { No } \\
\text { own }\end{array}$ & $\%$ \\
\hline 1 & $\begin{array}{l}\text { National } \\
\text { test }\end{array}$ & - & 0 & 77 & 96,25 & 3 & 3,37 \\
\hline
\end{tabular}

TABLE: VII PERCENTAGE OF ORIGIN OF KEY ANSWER WHEN FOLLOWING NATIONAL EXAMINATION.

\begin{tabular}{|l|l|l|l|l|l|l|l|}
\hline No & $\begin{array}{l}\text { Type of } \\
\text { Evaluation }\end{array}$ & Friends & $\%$ & Teacher & $\%$ & Others & $\%$ \\
\hline 1 & $\begin{array}{l}\text { National } \\
\text { test }\end{array}$ & 42 & 52,5 & 11 & 13,75 & 24 & 30 \\
\hline
\end{tabular}

Based on the above data, this means showing that the implementation of the National Examination, especially in Palu city, has shown less objective and accountable implementation in accordance with the Assessment Principles stipulated in the Regulation of the Minister of Education and Culture No. 23 of 2016.

\section{B. External Factors (Education Unit)}

It can not be denied that aside from the students, the factors of the school also influence the implementation of the learning evaluation followed by the students. Factors of the school are sourced from Master, Sararana and the infrastructure owned by the school. Teachers also contribute to the factors that influence the implementation of learning evaluations that students follow in school. The role of teachers, in this case, is like: - the form of assessment instruments made by teachers does not meet the elements of Validity, Student work is often not checked and not returned, the lack of understanding and attention of teachers in terms of supervision. Data on how the teacher behaved after a daily test, with the question: Did the teacher examine and return the results of the repetition performed? In the table below can be seen percentage figures.

TABLE: VIII PERCENTAGE OF STUDENT RESPONSES TO TEACHERS CHECKING AND RETURNING STUDENT WORK ( DAILY TEST )

\begin{tabular}{|l|l|l|l|l|l|l|l|}
\hline No & $\begin{array}{l}\text { Type of } \\
\text { Evaluation }\end{array}$ & Often & $\%$ & Rarely & $\%$ & Never & $\%$ \\
\hline 1 & Daily test & 7 & 8.75 & 3 & 3.75 & 70 & 87.5 \\
\hline
\end{tabular}

Based on the data, it indicates that in general or $87.5 \%$ of teachers who have performed daily tests to high school students in the city of Palu do not return the results of repetition to students. In terms of checking and returning the results of the repetition that has been done, it is very important to do. Knowing the results of the student's repetition after the repetition, it is very important for students and teachers, because then for students will foster the spirit of high learning motivation and for teachers, of course, will be a diagnostic material to determine the extent of the success of the learning process has been done. Then related to whether the test made by the teacher has been through the validity of the test? To this problem, the results of the interviews show that almost the majority of teachers stated "not performing test validity" except for a semester test. Besides the teacher, also do a daily test in oral form. Lack of understanding of most teachers (Supervisors) on how and fill the answer sheet when the National Examination took place, also become one of the factors that affect the implementation of the test conducted. Often students ask for an explanation from the teacher/supervisor about the technical procedures for filling out the answer sheets, but the teacher does not provide a satisfactory explanation. As a result, there are students who fill out the answer sheet not according to the provisions.

\section{CONCLUSION}

- The level of anxiety felt by high school students in the city of Palu at the time will follow the Evaluation of Learning Outcomes, the type of evaluation of the highest level of anxiety is at the time will follow the National Exam, with a very anxious percentage $91.25 \%$., Anxiety level The second is when following the Ultimate Semester with a Very Worried $8.75 \%$ Percentage, and the third is on following Daily Deuteronomy with a Very Worrying Percentage of $3.75 \%$.

- The highest rate of fraud occurring at the Evaluation of Learning Outcomes, ie repeat semester $81.25 \%$, while the daily test only $40 \%$. The cause of the high percentage of the frequency of fraud during the semester test is due to the teacher's lack of supervision in conducting the supervision, while the daily test of the supervision is quite strict.

- In general or $87.5 \%$ of teachers who have performed daily tests to high school students in the city of Palu do not return the results of repetition to students. In addition, the problems that teachers make for daily tests, generally do not pass the validity test, except for a small part of the semester test.

\section{REFERENCES}

[1] Permendikbud No. 23 tahun 2016, Tentang Evaluasi Pendidikan.

[2] Permendikbud No. 23 tahun 2016, Tentang Evaluasi Pendidikan

[3] Atkinson.K.C dan Benn,D.J (1996), Pengantar Psikologi II. Edisi XI (terjemahan Kusuma,W) Jakarta : Erlangga.

[4] Anwar, S. (1988). Sikap Manusia. Yogyakarta: Liberty

[5] Novitasari. I. 2004. ' Sindikasi Jual-Bel Kunci Jawaban Ujian Nasional 2010 ( Studi Kasus Jaringan Jual-Beli Kunci Jawaban Ujian Nasional 2010 di Kota X )', Jurnal Kriminologi Indonesia Vol. 7 No. II Oktober $2011: 267-286268$

[6] Anonim.2011. Academic Cheating ( Kecurangan Akademik ) http://makkita.wordpress.com/2011/03/ 24/academic-cheatingkecuranganakademik/ [ diakses 23 Desember 2016].

[7] Anderman, E.M. \& Murdoch, B.E, (2007). Psychology of Academic Cheating. Elsevier Academic. Press Publication : USA

[8] Bower, Deighton (dalam Alhadza. Abdullah) (2004). Masalah Menyontek (Cheating) di dunia pendidikan. http://www. Depdiknas.go.id/jurnal/ 2013/02/20

[9] Abel, Gizela (2012). Menghilangkan Bubaya Menyontek di kalangan Remaja. http://abelabela.blogspot.com/2013/05/21. 